\title{
Two rumen-protected amino acids in dairy cows' feed change the protein content of milk
}

\author{
Jo May Chow $\square \quad$ Edward J. DePeters $\square \quad$ R. Lee Baldwin
}

\section{Including fat in the diet of dairy cows often results in a decrease in the concentrations of total protein and casein in milk. In this study, the addition of rumen-protected methionine and lysine to such a diet increased the total protein and casein contents of milk produced by lactating cows.}

In California, cheese production increased dramatically in the 10 years ending in 1987 , going from 126 to 493 million pounds. As more milk is used for manufactured dairy products, more pricing systems are being set on the basis of the milk's protein make-up. Milk producers are looking for connections between dairy cow nutrition and protein concentrations in the cows' milk.

In research at UC Davis, fat fed to dairy cows led to a decrease in the milk's total

\begin{tabular}{|c|c|c|c|}
\hline \multirow[b]{2}{*}{ Item† } & \multicolumn{2}{|c|}{$\begin{array}{l}\text { Mixed } \\
\text { rations* }\end{array}$} & \multirow{2}{*}{$\begin{array}{l}\text { Top- } \\
\text { dress }\end{array}$} \\
\hline & $\mathrm{HF}$ & $\mathrm{HC}$ & \\
\hline & ......... &..$\%$ & (n........ \\
\hline \multicolumn{2}{|l|}{ Ingredient } & 25.2 & - \\
\hline Beet pulp & 5.0 & 25.2 & - \\
\hline Molasses & 4.2 & 4.2 & 7.7 \\
\hline Cottonseed meal & 8.5 & 15.1 & - \\
\hline Corn, cracked & 25.7 & 27.4 & - \\
\hline Fat & 3.9 & - & - \\
\hline Trace mineral salt & .5 & .5 & - \\
\hline Dicalcium phosphate & 1.1 & 1.1 & - \\
\hline Limestone & - & .6 & - \\
\hline Sodium bicarbonate & .8 & .8 & - \\
\hline Barley & - & - & 92.3 \\
\hline \multicolumn{4}{|l|}{ Chemical component } \\
\hline Crude protein & 17.6 & 17.1 & 12.1 \\
\hline Ether extract & 4.6 & 1.0 & 1.7 \\
\hline Acid detergent fiber & 21.9 & 18.9 & 8.0 \\
\hline $\begin{array}{l}\text { Neutral detergent } \\
\text { fiber }\end{array}$ & 34.5 & 33.4 & 19.3 \\
\hline Calcium & 1.0 & 1.0 & - \\
\hline Phosphorus & 6 & .6 & - \\
\hline
\end{tabular}

protein content (total $\%$ protein $=$ total $\%$ nitrogen $\times 6.38$ ) and casein content. Diets that were high in concentrate ingredients but had no added fat led to increases in the total protein and casein concentrations. Apparently, dairy cow nutrition can influence the total protein and casein content of the cows' milk.

\section{Casein variants}

The process by which the mammary gland synthesizes protein is similar to the process employed by other tissues. Amino acids absorbed from the bloodstream are linked together in peptide bonds through energyrequiring reactions to create proteins. The mammary gland synthesizes proteins in two broad families (caseins and whey proteins), along with smaller quantities of other proteins (e.g., lactoferrin).

Casein includes at least four gene products: alpha $S_{1}$ caseins, alpha $S_{2}$ caseins, beta caseins, and kappa caseins. These products account for approximately $78 \%$ of the total nitrogen in milk, depending on the cow's diet, parity, and stage of lactation. Within each casein are different genetic variants (e.g., variants A and B of kappa casein). The gene frequency of these variants differs among breeds, and this contributes to the characteristic processing properties of milk from different breeds.

The B variants of the beta and kappa caseins have been related to improved cheese manufacturing properties in milk, including firmer curd formation and a shorter rennet coagulation time. Jersey cows have frequencies of $86 \%$ for the $B$ variant and $14 \%$ for the A variant of kappa casein, compared Holstein cows, who have frequencies of $18 \%$ for the $B$ variant and $82 \%$ for the $A$ variant (data from Joel Van Eenennaam and Juan Medrano, UC Davis). This difference contributes to the superior cheese-manufacturing properties of Jersey milk.

Sire summaries today put more emphasis on a bull's predicted ability to transmit total protein characteristics, although casein should be getting more attention. Bulls used for artificial insemination programs in the future may be chosen for casein and for specific genetic variants of casein. Such programs could be used to tailor the protein composition of a herd's milk to a specific market demand, such as cheese production. J. F. Medrano (UC Davis) is researching the genetic variability of the casein genes. Advances in genetic technology will eventually allow researchers to control protein synthesis in the mammary gland by inserting genes

\begin{tabular}{|c|c|c|c|c|}
\hline \multirow[b]{3}{*}{ Item } & \multicolumn{4}{|c|}{ Ration* $^{*}$} \\
\hline & \multicolumn{2}{|c|}{ HF } & \multicolumn{2}{|c|}{$\mathrm{HC}$} \\
\hline & -RPAA & +RPAA & -RPAA & +RPAA \\
\hline \multicolumn{4}{|c|}{ Composition of milk } & (................. \\
\hline Fat & $3.50 \mathrm{a}$ & $3.49 \mathrm{a}$ & $3.15 b$ & $3.17 \mathrm{~b}$ \\
\hline Total solids & 12.16ab & $12.21 \mathrm{a}$ & $11.93 b$ & $11.93 b$ \\
\hline Protein & $2.86 a$ & $2.97 b$ & $2.97 b$ & $3.03 b$ \\
\hline Casein & $2.19 a$ & $2.29 b$ & $2.29 b$ & $2.34 b$ \\
\hline Whey & $.48 \mathrm{a}$ & $.45 a$ & $.52 b$ & $.52 b$ \\
\hline \multicolumn{5}{|c|}{ Nonprotein } \\
\hline nitrogen & $.19 a$ & $.19 a$ & $.17 b$ & $.17 b$ \\
\hline \multicolumn{5}{|c|}{ Composition of total protein } \\
\hline Casein & 76.4 & 77.0 & 76.9 & 77.1 \\
\hline Whey & 17.0 & 16.6 & 17.4 & 17.2 \\
\hline \multicolumn{5}{|l|}{ Nonprotein } \\
\hline nitrogen & $6.6 \mathrm{a}$ & $6.4 \mathrm{a}$ & $5.8 b$ & $5.7 \mathrm{~b}$ \\
\hline
\end{tabular}


for specific caseins and by regulating gene expression.

\section{Whey proteins}

The major whey proteins, alpha lactalbumin and beta lactoglobulin, are synthesized by a cow's mammary tissue. Other whey proteins enter the gland pre-formed from the bloodstream, and include immunoglobulins and bovine serum albumin. Whey proteins constitute about $17 \%$ of the total nitrogen in milk. Somegenetic variants of themammarysynthesized whey proteins are important in milk's manufacturing properties, although their importance cannot be understood without further research.

\section{Methionine and lysine}

The amino acids that reach a cow's small intestine and can thus enter her circulatory system are the microbial proteins and feed proteins that have escaped degradation by the rumen microbes. Because the amino acid composition of microbial protein is relatively constant, feed protein that escapes degradation in the rumen (undegradable protein) can have a major effect on the balance of amino acids available to the animal and hence to the synthesis of milk protein. Ruminantdiets are formulated with degradable and undegradable protein, but the

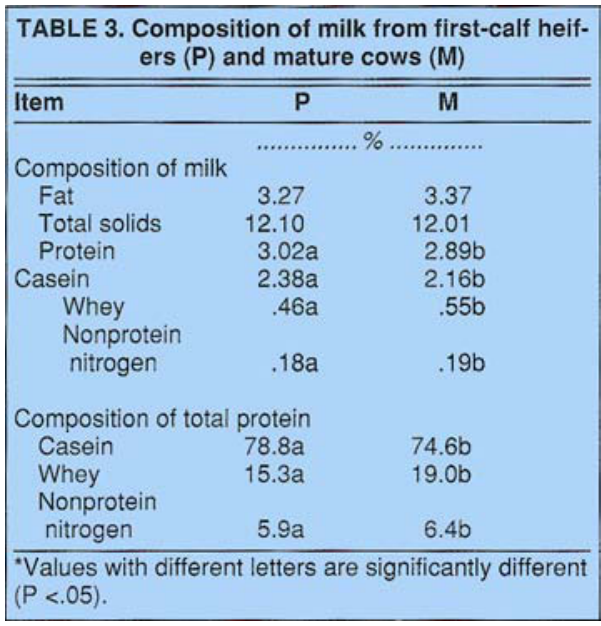

undegradable protein may not always provideoptimal quantities of the specific amino acids required for milk protein synthesis.

Reported research indicates that two amino acids - methionine and lysine may be co-limiting for milk protein synthesis when cows are fed corn-based diets. Methionine and lysine have been shown to possess low uptake-to-output ratios in the mammary gland, suggesting that they are limiting to milk protein synthesis.

The low uptake may be related to corn protein, a poor source of lysine and methionine. If amino acids are not supplied in sufficient quantities and correct proportions, they will limit protein synthesis. Future nutritionists may be able to predict the quantity and composition of feed protein that will escape ruminal degradation. With this knowledge, they should actually beable to balance dairy rations for the specific amino acids that will absorb in the small intestine.

\section{Rumen-protected amino acids}

Toprovideadditional methionine and lysine to the small intestine, we used a protected amino acid product in corn-based diets. The protected amino acids were coated with a pH-sensitive copolymer of styrene and 2methyl-5-vinylpyridine. The coating resists breakdown at rumen $\mathrm{pH}$ levels, and consequently protects the amino acids from being degraded by the rumen microbes. As the protected aminoacids pass to theabomasum, its acidic environment releases them from their protective coating. The amino acids becomeavailable for absorption by the small intestine, and for subsequent transportation to tissue sites for use in protein synthesis.

Our experimental objective was to evaluate the effect of rumen-protected methionine and lysine on the protein content of milk from cows fed corn-based diets that contained either added fat or high-concentrate ingredients.

\section{Methods}

Four first-calf heifers (primiparous) and four mature, second- or greater lactation (mul-

\begin{tabular}{|c|c|c|c|c|c|c|}
\hline \multirow{3}{*}{ Item } & \multicolumn{4}{|c|}{ Ration ${ }^{*} \dagger$} & \multirow{2}{*}{\multicolumn{2}{|c|}{ Parity $\neq$}} \\
\hline & \multicolumn{2}{|c|}{$\mathrm{HF}$} & \multicolumn{2}{|c|}{$\mathrm{HC}$} & & \\
\hline & -RPAA & +RPAA & -RPAA & +RPAA & $P$ & $M$ \\
\hline$\overline{\text { Milk (kg/day) }}$ & 32.6 & 33.6 & 30.4 & 32.8 & $27.9 a$ & $37.6 b$ \\
\hline $\begin{array}{l}\text { Dry matter intake } \\
(\mathrm{kg} / \text { day })\end{array}$ & 21.7 & 21.3 & 19.6 & 22.3 & $18.0 \mathrm{a}$ & $24.9 b$ \\
\hline $\begin{array}{l}\text { Milk components } \\
\text { Fat (g/day) } \\
\text { Protein (g/day) } \\
\text { Casein (g/day) }\end{array}$ & $\begin{array}{c}1,150 a b \\
931 \\
715\end{array}$ & $\begin{array}{c}1,200 a \\
989 \\
759\end{array}$ & $\begin{array}{l}950 c \\
900 \\
689\end{array}$ & $\begin{array}{c}1,050 \mathrm{bc} \\
989 \\
766\end{array}$ & $\begin{array}{l}920 a \\
836 a \\
638 a\end{array}$ & $\begin{array}{r}1,280 b \\
1,085 b \\
829 b\end{array}$ \\
\hline $\begin{array}{l}\mathrm{HF}=\text { high fat; } \mathrm{H} \\
\text { with rumen-protec } \\
\dagger \text { Values with diffe } \\
\ddagger \mathrm{P}=\text { primiparous }\end{array}$ & $\begin{array}{l}\text { high conce } \\
\text { lysine and } \\
\text { it letters wit }\end{array}$ & a categ & or $\mathrm{Pa}$ & are sig & dd methic & $\begin{array}{l}\text { ne; +RPAA } \\
.05) \text {. }\end{array}$ \\
\hline
\end{tabular}

tiparous) Holstein cows were used in a replicated $4 \times 4$ Latin square design. The experiment was divided into four periods of 21 days each. At the beginning, cows averaged 37 days in milk. Cows were kept in loose housing and fed twice a day through Calan electronic feed gates, to allow individual feeding.

Diets were either 50:50 forage-to-concentrate with $3.9 \%$ added fat (high fat, $H F$ ) or 25:75 forage-to-concentrate (high concentrate, $H C$ ) with no added fat (table 1). The fat sourcewas a commercially purchased yellow grease. Rumen-protected amino acids (RPAA) of methionineand lysine wereadded at 0 (-RPAA) or 55.1 (+RPAA) grams per day to the $\mathrm{HF}$ and $\mathrm{HC}$ diets, resulting in four dietary treatments: $\mathrm{HF}-\mathrm{RPAA}, \mathrm{HF}+\mathrm{RPAA}$, HC - RPAA, and HC + RPAA. The RPAA product was mixed into 0.4 kilograms of a barley-molasses mixture (table 1) and fed twice a day as a topdressing, providing each cow with 6.39 grams of DL-methionine and 19.99 grams of L-lysine daily at the small intestine.

Cows were milked two times a day, and yieldswere recorded. Milksamples collected from each cow during week 3 of each period were analyzed for fat, total protein (total \% nitrogen $\times 6.38$ ), casein, whey protein (whey protein nitrogen $\times 6.38$ ), nonprotein nitrogen (NPN), and total solids content. The data were statistically analyzed as a replicated Latin square design.

\section{Results}

Milk fat and total solids were significantly lower for cows on the HC diet than for cows on the HF diet (table 2). Total milk protein was lowest on the HF diet without protected amino acids (HF-RPAA), averaging $2.86 \%$. Adding protected amino acids ( $\mathrm{HF}+\mathrm{RPAA})$ increased milkproteinsignificantly, to $2.97 \%$, equal to the milk resulting from the $\mathrm{HC}$ diet without protected amino acids (HC-RPAA). Adding protected amino acids to the $\mathrm{HC}$ $\operatorname{diet}(\mathrm{HC}+\mathrm{RPAA})$ increased the milk protein, but not significantly.

Adding RPAA to cows' feed increased the casein content of their milk (table 2). Casein content of milk increased significantly, from $2.19 \%$ for cows fed HF - RPAA to $2.29 \%$ for those fed HF + RPAA. Inclusion of protected amino acids in the $\mathrm{HC}$ diet resulted in a nonsignificantincrease in casein, from $2.29 \%$ (HC - RPAA) to $2.34 \%$ ( $\mathrm{HC}+$ RPAA).Cowseating eitherHCdietproduced milk higher in whey protein and lower in NPN.

Dietary treatments did not alter the proportion of total milk nitrogen represented by casein and whey protein (table 2). However, the milk from cows receiving $\mathrm{HF}$ diets had a significantly greater proportion of nitrogen associated with the NPN fraction, 
approximately $6.5 \%$ versus $5.7 \%$ for cows fed $\mathrm{HC}$ diets.

The fat and total solids composition of milk did not differ with the cows' parity, but milk from primiparous cows had more total protein than milk from multiparous cows (table 3). The change in milk composition with the cows' parity confirms the results of other reported research.

First-calf heifers produced milk higher in casein and lower in whey protein and nonprotein nitrogen than did mature cows (table 3). Unlike mature cows, first-calf heifers had a significantly greater proportion of their total milknitrogen associated with the casein component, and less with the whey and nonprotein nitrogen components. First-calf heifers had about $79 \%$ of their total milk protein in the casein component, compared to only $75 \%$ for mature cows.

Milk yields did not differ among treatments, but the HC - RPAA diet tended to producea lower milkyield (table4). A similar pattern could be observed for intake of dry matter. Yields of total protein and casein tended to increase when protected amino acids wereincluded in the diet. Casein yields increased from 689 to 766 grams per day with addition of RPAA to the HC diet. Similarly, casein increased from 715 to 759 grams per day when RPAA was added to the HF diet.

Parity responses were as expected. Mature cows produced more milk and consumed more dry matter than primiparous cows. They also produced more fat, total protein, and casein than primiparous cows, reflecting the higher production potential of the mature cows.

\section{Conclusion}

Nutrition programs can alter milk protein. By providing methionine and lysine to dairy cows, we increased the casein content of their milk. Researchers should continue to look at ways to use nutritional programs to modify the protein composition of cows' milk. One day, dairies may produce milk for specific markets, whether to be used in fluid form or in the form of a specificmanufactured product. Large dairies may eventually segregate milk on the basis of its composition, such that they will store the higher-protein milk of first-calf heifers separately from the milkofmaturecows. Researchmustcontinue to help the producer meet the changing market demands.

Jo May Chow is Graduate Student, Edward J. DePeters is Associate Professor, and R. Lee Baldwin is Professor, Department of Animal Science, UC Davis. This research was supported by the California Milk Advisory Board and the University of California Agricultural Experiment Station. The authors thank Eastman Chemical Co.for providing the rumen-protected methionine and lysine.

\section{A new race of downy mildew threatens spinach}

\author{
James C. Correll $\square \quad$ Steven T. Koike $\square \quad$ Lynn P. Brandenberger \\ Mark C. Black 口 Teddy E. Morelock
}
A new race of downy mildew is threatening spinach in several California and Texas growing areas. Two fungicides, metalaxyl and Aliett, may help control the disease.

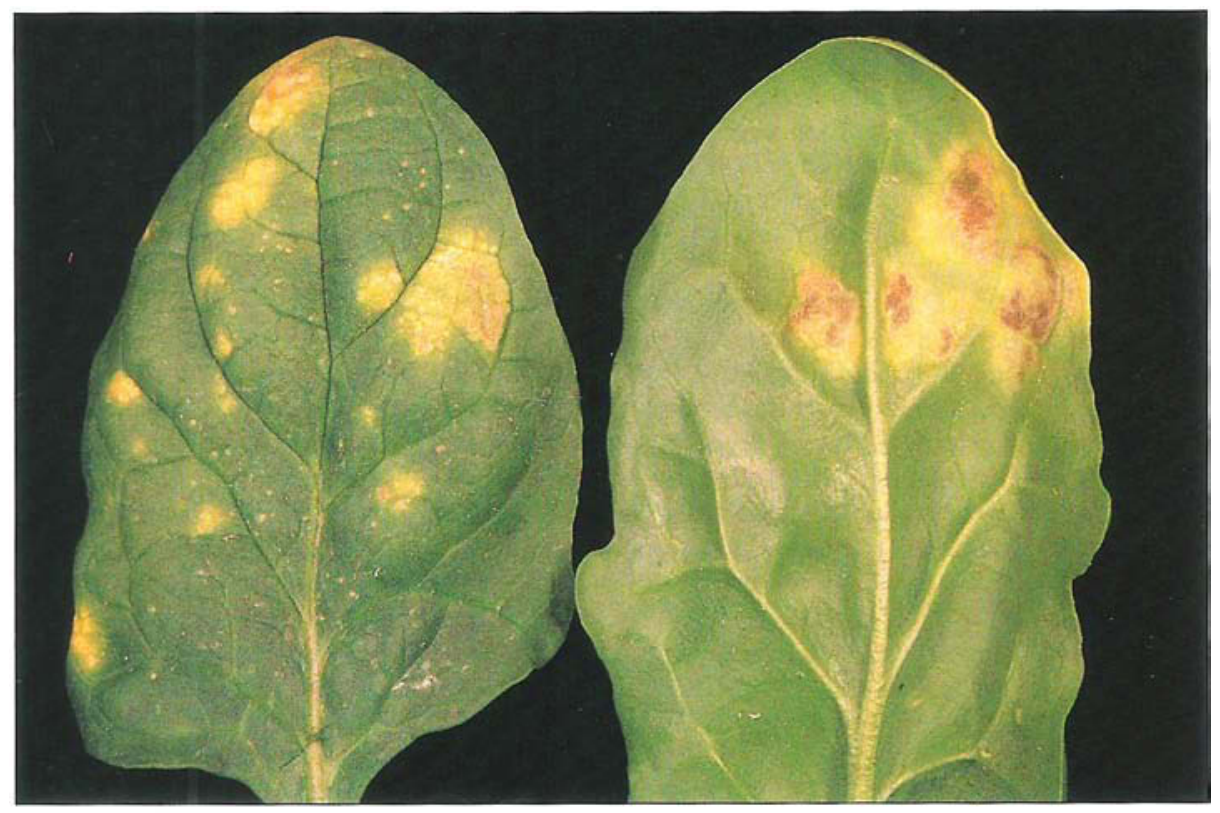

Race 4 of downy mildew inflicts progressive damage on spinach leaves. At first, small chlorotic lesions appear (top). These spread, and can turn bluish gray (left) in moist conditions, or white or tan (right) in dry conditions.

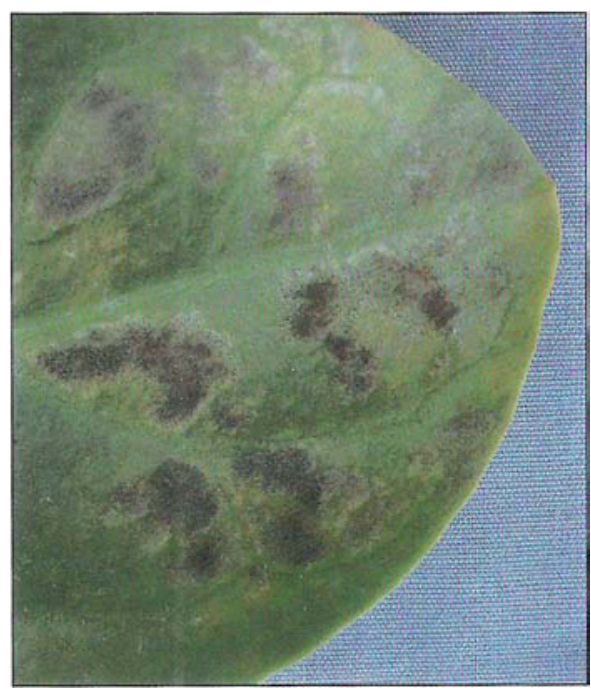

